The Indian Economy Sixty Years After Independence 
Also by Raghbendra Jha:

Raghbendra Jha (editor)

ECONOMIC GROWTH, ECONOMIC PERFORMANCE AND WELFARE IN SOUTH ASIA

Raghbendra Jha (editor)

INDIAN ECONOMIC REFORMS

Raghbendra Jha and K. V. Bhanu Murthy (authors)

ENVIRONMENTAL SUSTAINABILITY

A Consumption Approach

Raghbendra Jha (author)

MACROECONOMICS FOR DEVELOPING COUNTRIES

Raghbendra Jha (author)

MODERN PUBLIC ECONOMICS

Raghbendra Jha and B.S. Sahni (authors)

INDUSTRIAL EFFICIENCY

An Indian Perspective

Raghbendra Jha (editor)

THE FIRST TEN K.R. NARAYANAN ORATIONS

Essays by Eminent Persons on the Rapidly Transforming Indian Economy

Raghbendra Jha (author)

CONTEMPORARY MACROECONOMIC THEORY AND POLICY

Raghbendra Jha (author)

MODERN THEORY OF PUBLIC FINANCE 


\section{The Indian Economy Sixty Years After Independence}

Edited by

Raghbendra Jha 
Selection and editorial matter (c) Raghbendra Jha 2008 Individual chapters (C) Contributors 2008

Softcover reprint of the hardcover 1st edition 2008 978-0-230-21835-2

All rights reserved. No reproduction, copy or transmission of this publication may be made without written permission.

No portion of this publication may be reproduced, copied or transmitted save with written permission or in accordance with the provisions of the Copyright, Designs and Patents Act 1988, or under the terms of any licence permitting limited copying issued by the Copyright Licensing Agency, Saffron House, 6-10 Kirby Street, London EC1N 8TS.

Any person who does any unauthorized act in relation to this publication may be liable to criminal prosecution and civil claims for damages.

The authors have asserted their rights to be identified as the authors of this work in accordance with the Copyright, Designs and Patents Act 1988.

First published 2008 by

PALGRAVE MACMILLAN

Palgrave Macmillan in the UK is an imprint of Macmillan Publishers Limited, registered in England, company number 785998, of Houndmills, Basingstoke, Hampshire RG21 6XS.

Palgrave Macmillan in the US is a division of St Martin's Press LLC, 175 Fifth Avenue, New York, NY 10010.

Palgrave Macmillan is the global academic imprint of the above companies and has companies and representatives throughout the world.

Palgrave ${ }^{\circledR}$ and Macmillan ${ }^{\circledR}$ are registered trademarks in the United States, the United Kingdom, Europe and other countries.

\section{ISBN 978-1-349-30431-8 ISBN 978-0-230-22833-7 (eBook) \\ DOI $10.1057 / 9780230228337$}

This book is printed on paper suitable for recycling and made from fully managed and sustained forest sources. Logging, pulping and manufacturing processes are expected to conform to the environmental regulations of the country of origin.

A catalogue record for this book is available from the British Library.

A catalog record for this book is available from the Library of Congress.

$\begin{array}{rrrrrrrrrrr}11 & 10 & 9 & 8 & 7 & 6 & 5 & 4 & 3 & 2 & 1 \\ 18 & 17 & 16 & 15 & 14 & 13 & 12 & 11 & 10 & 09 & 08\end{array}$




\section{Table of Contents}

Preface

vii

List of Figures

ix

List of Tables

$\mathrm{xi}$

Authors' Affiliations

xiii

Acknowledgements

1. Introduction to the Volume

Raghbendra Jha

Part I: Mega Trends in India - Economics and Politics

2: Coalitions and Consequences: Historical, Economic,

Social and Political Considerations from India

Robin Jeffrey

3: The Indian Economy: Current Performance and

Short-run Prospects

Part II: Emerging Issues in Fiscal Policy in India

4: A Decade of World Bank Sub-National Policy-Based Lending

to India: A Retrospective

Stephen Howes, Deepak Mishra \& VJ Ravishankar

5: Pension Reform in India

Mukul Asher

Part III: India's External Sector

6: Export Performance in the Reform Era: Has India Regained the Lost Ground?

Prema-chandra Athukorala

7: Manufacturing Protection in India Since Independence

Garry Pursell, Nalin Kishor and Kanupriya Gupta

8: Free Trade Arrangement between India and Japan:

An Exploratory Analysis

K. Kalirajan and Swapan Bhattacharya

Part IV: Trends and Prospects for India's Social Sector

9: Human Development in India: Past Trends and Future Challenges

Anil Deolalikar

10: Microfinance, Self-Help Groups and Empowerment in Maharashtra

Raghav Gaiha and Mani Nandhi

11: Urban Vulnerability Reduction: Regulations \& Beyond

V. Thiruppugazh

Part V: Sectoral Issues

12: Agricultural Trade Policies and Rural Poverty:

Where is India Heading?

Garry Pursell and Peter Warr 
13: Market Integration in Indian Agriculture

Raghbendra Jha, K.V. Bhanu Murthy and Anurag Sharma

14: Supermarkets, Smallholders and Livelihoods Prospects in

Selected Asian Countries

Raghav Gaiha and Ganesh Thapa

15: Privatisation and Foreign Direct Investment: The Indian Experience

T T Ram Mohan

16: India’s Great Vulnerability: Energy Insecurity

Rakesh Ahuja

17: Economic Determinants of Newsprint Consumption in India:

A Time Series Analysis

Raghbendra Jha and U.N. Bhati

Index 


\section{Preface}

2007 marked 60 years of Indian independence, a period in which a country that is home to a sixth of the world's population, has gone through immense transformation. The persistent image of India as a nation unable even to feed its population has been replaced with that of a country that is being called an innovation powerhouse, a knowledge economy at the forefront of key scientific research, indeed a country where the interface between research and innovation is being re-defined.

However, this sanguine outlook is only of recent origin. To be sure the Nobel Laureate poet Rabindranath Tagore moved by India's colonial experience wrote of India a few years before independence (in 1941) that '... perhaps in no other modern state was there such hopeless dearth of the most elementary needs of existence.' The implications of this dire economic condition were compounded, in the eyes of many observers, by the granting by the Indian constitution, almost immediately after independence, of universal adult franchise within a democratic parliamentary set-up. This was at a time when some of the major Western powers had not granted full voting rights to all their population. It was widely felt in the 1950s and 1960s (and perhaps even later) that such an audacious experiment was a recipe for disaster.

Yet India has proved these commentators wrong. From some of these same quarters one hears comments like the $21^{\text {st }}$ century is India's century. Although there is much that is remarkable in India's emergence on the world stage as a major economic power several challenges remain, some like poverty have been persistent while the growth process itself has thrown up new challenges, like addressing increasing regional inequality, or designing purposeful economic policy in an era of coalition governments.

The present volume does not portend to be a comprehensive analysis of the Indian economy sixty years after independence. Indeed it would be overly ambitious to attempt such a task. Rather, this book is an attempt to examine key areas of the Indian economic experience closely with the subsidiary aim of being able to anticipate future developments.

The papers in this volume were presented at a conference to mark 60 years of Indian independence in August 2007 by Australia South Asia Research Centre, Australian National University. I am grateful to all the scholars who presented papers at the conference and then undertook the non-trivial task of transforming conference presentations into major scholarly articles. At Palgrave Macmillan Taiba Batool and Alec Dubber were most gracious and helpful during the preparation of the manuscript for publication. ASARC administrator, Stephanie Hancock, organised every detail of this conference and prepared the manuscript for final publication. I really cannot thank Stephanie enough for her many contributions to the conference and this volume.

Mark Twain once famously said that 'India is, the cradle of the human race, the birthplace of human speech, the mother of history, the grandmother of legend, and the great grand mother of tradition. Our most valuable and most instructive materials in the 
history of man are treasured up in India only.' This country of traditions now has a population of 1.1 billion with a median age of 24.9 years! Hence there is much that is exciting and vibrant that is unfolding. This book tries to capture some of the economic dimensions of India's transformation.

\section{Raghbendra Jha}

Canberra, February 2008 


\section{List of Figures}

Figure 3.1: Sectoral Composition of India's GDP 22

Figure 3.2: Investment in Indian Agriculture $\quad 30$

Figure 3.3: Agricultural Subsidies at 2000-01 Prices (Rs. Billion) 30

Figure 4.1: State Deficit and Debt 1991-2007 45

Figure 4.2: Fiscal Deficit (\% of GSDP) 57

Figure 4.3: Government Debt (\% of GSDP)

Figure 4.4: Fiscal Deficit to GSDP ratio (in \%)

Figure 5.1: India's Social Security System: An Overview $\quad 74$

Figure 5.2: Interest Rates: EPF Payouts vs Earned $\quad 78$

Figure 6.1: India's Share in Total World Exports and Exports

from Developing Countries, 1962-2006 97

Figure 6.2: Export Orientation of the Indian Economy:

Exports as a parentage of GDP, 1970-2005 98

Figure 6.3: India and China: Share in World Textile and Clothing Exports, 1970-2006

Figure 6.4: India: Factor Intencity Classification of Merchandise Exports, 1976-2005

Figure 7.1: Shares of Tradable Manufacturing Value Added subject to Import QRs

Figure 7.2 Indicators of Manufacturing Protection 1965-2007

Figure 7.3 Indian Manufacturing: Implicit Protection and the

Real Effective Exchange Rate

Figure 7.4 Manufactured Imports, Exports and the Real Effective

Exchange Rate 1971-2006

Figure 9.1: Infant Mortality by Sector, 1971-2005 156

Figure 9.2: Infant Mortality Rates, 1970-2000, Selected Countries in Asia 156

Figure 9.3: Annual percentage Decline in Infant Mortality Rate

1981-2005 Across States Plotted against State's Level in 1981

Figure 9.4: Annual rate of IMR Decline by State, 1981-2005

Figure 9.5: Regional Estimates of the Change in the Infant Mortality Rate, 1988-92 to $1994-98$

Figure 9.6: Percentage of Births Occurring in an Institution

(as opposed to home) by State 1992-93 to 2005-06

Figure 9.7: Percentage of Children 12-23 months Fully Immunised,

by State $1992-93$ to $2005-06$

Figure 9.8: Percentage of Children under 3 yrs who are Underweight

or Stunted in India, 1992-93 to 2005-06

Figure 9.9: Percentage of children under 3 yrs who are Underweight

by Residence and Mother's Schooling in India, 2005-06

Figure 9.10: Children under 3 yrs who are Underweight

by State, 1992-93 to 2005-06 
Figure 9.11 Calorie, Protein and Fat Intake per person per day

by Residence, 1972-73 to 2004-05

Figure 9.12 Changes in Nutrient Consumption per capita per day,

Rural Areas, 1972-73 to 2004-05

Figure 9.13: Calorie, Protein and Fat Intake per person per day,

by state, 2004-05

Figure 9.14: Average Years of Schooling by Sex and Ratio of

Female Schooling to Male Schooling by Year of Birth.

Figure 9.15: Average years of Schooling by Sex, Year of Birth and State

Figure 9.16: Percentage Growth in Mean Schooling Year

over Two Periods in the $20^{\text {th }}$ Century by State

Figure 9.17: School Attendance Rate (\%) by Age and Sex

1993-94 and 2004-05

Figure 9.18: Percentage Increase in School Attendance Rate between 1992-93 and 2004-05, by Sex

Figure 9.19: School Attendance Rates among Males, aged 6-11,

by State 1993-94 and 2004-05

Figure 9.20: School Attendance Rates among Females, aged 6-11,

by State 1993-94 and 2004-05

Figure 9.21: School Attendance Rates among Females as a \%

of those among Males, Aged 6-11, by State 1993-94 and 2004-05

Figure 9.22: School Attendance Rates among Females as a \%

of those among Males Aged 12-15, by State, 1993-94 and 2004-05

Figure 9.23: School Attendance Rates among Females as a \%

of those among Males Aged 16-17, by State, 1993-94 and 2004-05

Figure 9.24: Aggregate and Juvenile Sex Ratio in India, 1871-2001

Figure 9.25: Juvenile (0-6 Years) Sex Ratio, by State, 1971-2001 176

Figure 10.1: Targeting of SHGs 188

Figure 12.1: India 1965-2005: Agriculture Vs Manufacturing Protection 230

Figure 13.1: Government Intervention in Wholesale Grain Trade 244

Figure A14.1: Supermarkets — Fitted Vs. Actual Dependent Variables 262

Figure 17.1: Production, Exports, Imports and Consumption of Newsprint, India 289

Figure 17.2: Annual Consumption of Newsprint, 2005

Figure 17.3: Consumption of Newsprint, Real Wholesale Price of Newsprint, and Real GDP in India (Natural Logarithms) 


\section{List of Tables}

Table 3.1: Comparative Macroeconomic Performance of India and Britain, $1600-1947$

Table 3.2: Levels of GDP per capita in European Colonial Powers and

Former Colonies, 1500-1998

Table 3.3: Growth of per capita GDP in European Colonial Powers and

Former Colonies, 1500-1998

Table 3.4: Some Basic Characteristics of Growth of Real GNP in India

Table 3.5: Growth Rates of Real GDP

Table 3.6: Sources of Growth in India: Aggregate and by Major Sectors

Table 3.7: Savings and Investment in India

Table 3.8: India: Key Fiscal Indicators

Table 3.10: Commodity Composition of India's Exports

Table 3.11: India's Merchandise Trade

Table 3.12: Invisibles Account (Net) US\$ million

Table 3.13: India: Automobile Production and Export

Table 3.14: Average Growth Rates of Area, Production and Yield under Foodgrains, Non-foodgrains and All Crops

Table 3.15: Standard Deviations, Means and Coefficients of Variation of

Real Net State Domestic Product per capita across India's States and Union Territories: 1993-94 to 2004-05

Table 3.16: Distribution of the Burden of Deprivation in Rural India

Table 3.17: Unemployment in India, Current Daily Status Basis

Table 4.1: Basic Information on Policy-Based Lending to Indian States by the World Bank

Table 4.2: Fiscal Deficit: Target vs. Actuals

$\begin{array}{lr}\text { Table 5.1: India: Selected Indicators of Macroeconomic Performance } & 70 \\ \text { Table 5.2: India: Labor Force and Demographic Indicators } & 71\end{array}$

Table 5.3: Contribution Rates for the Schemes of the EPFO 78

Table 5.4: Members' Balances (EPF) $\quad 79$

Table 6.1: Key Indicators of India's Export Performance, 1950-2005 98

Table 6.2: Manufacturing Exports from Developing Countries: Ranking of the Top Ten Exporting Countries in Ascending Order of Export Value, 1962/63, 1979/80, 1999/00 and 2005/06

Table 6.3: Commodity Composition of Merchandise Exports

Table 6.4: Share in World Manufacturing Exports, 1979/80, 1989/90 and 2005/06

Table 6.5: Exports of Machinery and Transport Equipment, 1989/90 and 2005/06

Table 6.6: India's Exports by 3-digit SITC Categories: Share in Total Exports,

World Market Share and RCA Indices

Table 6.7: Nominal Tariff in India and Some Asian Countries 
Table 6.8: Effective Rate of Protection (ERP) in Manufacturing in India and Some Asian Countries

Table 6.9: Indicators of Ease of Trading Across Border: India in the Regional Context, 2008

Table 6.10: Ease of Doing Business Ranking of Sleeted Asian Countries, 2008

Table 7.1: Nominal Protection Indicators for Selected Years, 1971-2006

Table 8.1: Import and Export Intensities of Japan and India, 1995-2005

Table 8.2: Maximum Likelihood Estimates of the Stochastic Frontier Gravity Equation for India's Exports to Partner Countries Including Japan

Table 8.3: Maximum Likelihood Estimates of the Stochastic Frontier Gravity

Equation for Japan's Exports to Partner Countries Including India

Table 8.4: Mean Efficiency of Exports of India and Japan

(Sectorwise), 2005

Table 8.5: Likely increase in India's exports to Japan under

Different PTAs and FTA, 2005

Table 8.6: Likely increase in Japan's exports to India under Different PTAs and FTA, 2005

Table 10.1: Features of Microfinance Approaches

Table 10.2: Rates of Return on Investment

Table 10.3: Indices of Empowerment

Table 12.1: Approximate \% Shares of Indian Farm Production

Consumed at the Farm in 2004-05

Table 12.2: India: Some Comparisons of Estimated Implicit

Nominal Protection Rates with NTBs and Tariffs

Table 13.1: List of 55 Centres for Rice Studied in this Chapter

Table 13.2: Common Factors across Various Wholesale Rice Markets in India

Table 13.3: Diagnostic Statistics for Various Common Factors

Table 13.4: Significance of Vector Error Correction Terms

Table 13.5: Absence of Market Integration in Markets Not Included in Table 13.2

Table 13.6: Average Government Supply as a percentage of Total Supply of Wheat (1970-95)

Table 14.1: Main Characteristics of Selected Case Studies

Table 14.2: Supermarket Shares in Selected Asian Countries in 2015

Table A14.1: Determinants of the Share of Supermarkets

(Ordinary Least Squares)

Table A 14.2: Determinants of the Share of Supermarkets (Robust Regression)

Table A 14.3: Determinants of Supermarket Share (Ordinary Least Squares)

Table A 14.4: Determinants of Supermarket Share (Robust Regression)

Table 15.1: Financial Indicators of India's Public Sector Banks

Table 15.2: Net pre-tax profit of banks (as \% of assets)

Table 15.3: Government shareholding in listed PSBs

Table 15.5: Industry-wise flows of FDI (US\$million)

Table 17.1: The press in India: key statistics

Table 17.2: Estimates of Newsprint Consumption Elasticities with

Respect to Newsprint Price and GDP

Table 17.3: Indicative Forecasts of Consumption of Newsprint in India, 


\section{Authors' Affiliations}

Rakesh Ahuja manages the Axessindia Consultancy Group, focussed on analysing developments in India and promoting Australia-India commercial projects.

Mukul G. Asher is Professor of Public Policy at the National University of Singapore.

Prema-chandra Athukorala is Professor of Economics in the Research School of Pacific and Asian Studies at the Australian National University.

Swapan Bhattacharya is with National Graduate Institute for Policy Studies and Indian Institute of Public Administration

U.N. Bhati is visiting fellow at The Australian National University's Fenner School of Environment and Society.

Anil Deolalikar is Professor of Economics and Director of the Public Policy Initiative at the University of California, Riverside.

Raghav Gaiha is Professor of Public Policy, Faculty of Management Studies, University of Delhi.

Kanupriya Gupta is Research Analyst at the New Delhi office of the International Food Policy Research (IFPRI).

Stephen Howes is Professor at the Crawford School, Australian National University.

Robin Jeffrey is Convener of the College of Asia and the Pacific, Director of RSPAS and Professor at the Australian National University.

Raghbendra Jha is Professor and Executive Director, Australia South Asia Research Centre, Australian National University.

Kaliappa Kalirajan is Professor GRIPS-FASID Joint Program, Tokyo.

Nalin Kishor is Coordinator for the Forest Law Enforcement and Governance (FLEG) program in the Sustainable Development Vice-Presidency of the World Bank.

Deepak Mishra is with the World Bank.

K.V. Bhanu Murthy is Professor of Economics, University of Delhi.

Mani Arul Nandhi is Reader, Department of Commerce, Jesus and Mary College, University of Delhi.

Garry Pursell is a Visiting Fellow at the Australia South Asia Research Centre, Australian National University.

T.T. Ram Mohan is Professor, Indian Institute of Management, Ahmedabad.

Anurag Sharma is Research Fellow, Monash University.

Ganesh Thapa is Regional Economist, Asia and the Pacific Division, International Fund for Agricultural Development.

V. Thiruppugazh is a senior officer of the Indian Administrative Service and a Ph.D. candidate at the Australian National University.

V.J. Ravishankar is with the World Bank.

Peter Warr is Professor of Agricultural Economics and Convener of the Economics Division, Research School of Pacific and Asian Studies, at the Australian National University. 


\section{Acknowledgements}

Tables 3.1, 3.2, and 3.3 are reprinted with permission from the copyright holders OECD. The editor acknowledges and thanks the OECD for granting this permission. Parts of chapter 13 were published in Economic and Political Weekly 40(53), December 2005. The editor is grateful to the editor of Economic and Political Weekly for granting permission for printing this material in the present volume. 